\title{
CHOICE OF REVASCULARIZATION TECHNIQUE IN PATIENTS WITH ISCHEMIC DIABETIC FOOT
}

\section{Shapovalov}

State Institution of Science «Research and Practical Center of Preventive and Clinical Medicine» State Administrative Department, Kyiv, Ukraine

\section{Summary}

Background. Ischemic diabetic foot is determined by trophic disorders of the foot due to a combination of atherosclerosis of the arteries and diabetic lesions. In the United States and some European countries, among major non-traumatic amputations, amputations in patients with diabetes are $45-70 \%$. The use of revascularization can significantly improve the results of treatment of patients with diabetic foot. Features of ischemic diabetic foot require a separate approach to revascularization. There are no generally accepted guidelines for revascularization in diabetic foot in the world today. The choice of revascularization technique remains an open question.

The aim of the study. To analyze the effectiveness of differentiated application of intervention techniques of revascularization for the treatment of ischemic diabetic foot.

Steps of differentiated choice of revascularization. We identified seven steps: determination of indications for revascularization, determination of the critical arterial segment. the level of hemodynamic compensation, determination of the feasibility of revascularization, the choice of revascularization technique, the perform revascularization, the active postoperative monitoring.

Materials and methods. Diabetic ischemic foot was diagnosed in 133 observations. 123 revascularizations of 94 lower extremities were performed in 91 patients with ischemic diabetic foot. Patients underwent angioplasty, surgical revascularization or hybrid intervention.

Results. Revascularization was performed in revascularization was performed in $92,4 \%$ of patients with ischemic diabetic foot. Amputation-free survival was noted in $85.4 \%$ of cases, wound-healing in $62.6 \%$, preservation of foot support function in $79.7 \%$, avoidance of repeated interventions in $78.9 \% .5(5.5 \%)$ patients died, 2 of them (2.2:\%) within 30 days after revascularization.

Conclusions: Differentiated choice of revascularization technique allows to increase the number of patients to be revascularized $92,4 \%$, to reach of the level amputation-free survival to $85,4 \%$, to reach of the level woundhealing to $62,6 \%$, to salvage of foot support function to $79,7 \%$, to perform revascularizations in patients with a high probability of limb amputation.

Key words: peripheral arterial diseases, diabetic foot, revascularization, angioplasty, vascular surgery, endovascular treatment.

\section{INTRODUCTION}

Peripheral arterial diseases (PAD) are frequent pathology that significantly impairs the quality of life and leads to disability of people over 50 years. In the study PARTNERS (2001p.) [1] 6,979 people over the age of 50 were examined. Peripheral arterial diseases (PAD) were found in $1865(29 \%)$ patients. More than $80 \%$ of them had clinical signs, but only $49 \%$ were examined by their doctors and had a diagnosis.
The number of patients with diabetes, according to the WHO report for 2016 [2], in Ukraine is 9.1\% and tends to increase, both in our country and around the world.

Diabetics are 2.7 times more prone to peripheral artery disease than people of the same age without diabetes [3]. Atherosclerosis of the arteries of the lower extremities in combination with diabetes remains the main cause of non-traumatic major amputations of the lower extremities [4]. The generally accepted probability of risk of diabetic foot ulcers is $25 \%$ [4], according to some studies can reach $34 \%$ [5]. 
According to the International Diabetes Federation, diabetic foot ulcers occur annually in 9.1 million of the world's 26.1 million diabetics. In the United States and some European countries, among major non-traumatic amputations, amputations in patients with diabetes are $45-70 \%[7,8,9,10]$.

Of these, the combination of diabetes and peripheral artery disease is $37-47 \%$ of all amputations, without diabetes $-16.2 \%-22.1 \%$. [10,11]. After major amputations, the average life expectancy is $50 \%$, according to some data only 2 years [12], and 5-year mortality is 40-90\% [13]. One recent study [14] reported the following: after major amputation for ischemic diabetic foot, survival for 1 year was $41.7 \%$, for 5 years $-8.3 \%$.

The use of revascularization can significantly improve the results of treatment of patients with diabetic foot. Limb salvage after revascularization for 1 year is $78-85 \%$ compared with $54 \%$ in patients treated conservatively [15].

Today there are two basic and two derivative methods of revascularization.

The basic ones include surgical revascularization (open vascular surgery, bypass surgery), endovascular revascularization (angioplasty). Combining endovascular and surgical techniques within a single procedure is called hybrid revascularization.

The use of endovascular technique for targeted administration of thrombolytic drugs - catheter-directed thrombolysis. The task of revascularization in a patient with diabetic foot is to restore blood flow to at least one of the arteries of the foot, preferably the one that supplies the affected area [16].

Targeted restoration of blood flow in the most damaged areas of the foot became possible due to the angiosomal concept $[17,18]$. Current clinical guidelines for the choice of revascularization technique are Inter-Society Consensus for the Management of Peripheral Arterial Disease (TASC-II) [19] and Global Vascular Guidelines on the Management of Chronic Limb-Threatening Ischemia (CLTI) [20].

The recommendations of TASK-II (2007) do not currently take into account the current possibilities of endovascular revascularization.

The CLTI guidelines have specifically highlighted the limitations of using these guidelines in patients with diabetes due to the large difference between peripheral artery disease and ischemic diabetic foot [20].

A careful study of the studies on which these recommendations are based reveals a significant difference in the results of open, endovascular, and hybrid revascularizations, depending on the authors, clinics, and countries. The result of revascularization is obviously influenced by the experience of specialists, organizational and economic factors, both within the clinic and within the country.

\section{THE AIM OF THE STUDY}

To analyze the effectiveness of differentiated application of intervention techniques of revascularization for the treatment of ischemic diabetic foot.

We defined the goal of revascularization as improving the quality of life by preserving the limb. Tasks of revascularization are reduction of pain, avoidance of large amputation, healing of trophic disorders, preservation of functional capacity (support function) of the foot, sufficient for comfortable daily activity.

\section{STAGES OF DIFFERENTIATED REVASCULARIZATION ALGORITHM}

Step 1. Determination of indications for revascularization. Indication for revascularization is the presence of the ischemic diabetic foot.

Step 2. Determination of the critical arterial segment. The critical arterial segment, we considered the affected arterial area, which most changes the hemodynamics in the limb. The second necessary task was to determine the functional capacity of inflow arteries and outflow arteries.

Step 3. The level of hemodynamic compensation. Hemodynamic compensation was defined as the ratio of occlusive-stenotic arterial lesions and ischemia of foot scans.

Step 4. Determination of the feasibility of revascularization. Probability of successful revascularization. The feasibility of revascularization was determined by the risk-benefit ratio. We took into account: the probability of successful revascularization, the probability of progression of ischemia, trauma of the chosen technique, the forecast of preservation of functional ability of foot, daily activity of the patient.

the patient's needs for quality of life, predicted timing of recovery of patient activity.

Step 5. The choice of revascularization technique. First of all, we have always considered the possibility of angioplasty - «Angioplasty is the first strategy». When performing angioplasty, we tried to adhere to the angiosomal concept. Surgical revascularization was choosen in prolonged resistant occlusions with capable outflow arteries, local short occlusions of the bifurcation zone of the common femoral artery, Lerich's syndrome, ineffectiveness of previous endovascular intervention.

\section{Step 6. Perform revascularization.}

Step 7. Active postoperative monitoring. The monitoring periodlasted one year. The monitoring consisted of follow-up with ultrasound examinations, debridement, infection control, off-loading, daily walking and drug support 


\section{RESEARCH DESIGN}

Indications for revascularization.

Indications for revascularization were considered to be the presence of diabetic ischemic foot.

\section{Exclusion group.}

- patients with palpatory pulsation of the arteries of the foot,

- patients with intermittent claudication that has not progressed or has not significantly affected quality of life,

- patients with diabetes mellitus and peripheral arterial diseases without trophic disorders,

- patients who refused revascularization or went to another institution.

Indications for primary major amputation: the condition of the limb, which eliminates the possibility of maintaining the supporting function of the foot even after successful revascularization.

Clinical data. Preliminary planning of the method of intervention during the initial examination was based on the somatic condition of the patient, the local status of the lower extremity, palpation of the arteries of the lower extremities.

\section{ADDITIONAL EXAMINATIONS}

Ultrasound of the arteries of the lower extremities is a mandatory examination performed during the general examination for signs of ischemia.

CT angiography of the lower extremities. It was used mainly for lesions of the arteries of the 1st and 2nd order, when it is necessary to determine the exact size of the affected area (eg, aneurysm) or if the patient has the results of the examination at the first examination.

Angiography was planned to obtain additional information with the subsequent transition to the revascularization procedure according to one of the methods according to the obtained data.

\section{CRITERIA FOR EVALUATING THE RESULTS}

The following were chosen as criteria for evaluating the results: avoidance of major amputation, healing of trophic disorders. preservation of the supporting function of the foot, repeated surgical interventions.

Terms of evaluation of results.

The monitoring period was 12 months.

\section{MATERIALS AND METHODS}

Diabetic ischemic foot was diagnosed in 133 observations. Revascularization was considered inexpedient at the stage of the initial examination in 3 observations.

In 5 observations after angiography revascularization by any method was considered impossible
Attempts at revascularization were unsuccessful in 2 observations.

123 revascularizations of 94 lower extremities were performed in 91 patients with ischemic diabetic foot.

All patients (100\%) had trophic ischemic lesions of the foot, in three cases both lower extremities were affected $(2.4 \%)$.

All patients underwent angioplasty, surgical revascularization or hybrid intervention.

Sex. 73 revascularizations were performed in men (59.4\%), 50 in women (40.6\%). Age. By age, patients were divided into 2 groups: I - up to 65 years, II -65 years and older, the distribution by groups was 37 (30.8\%) and 83 (69.2\%), respectively.Ураження стопи.

There are three characteristics of foot lesions:

- WIFi classification category,

- type of ischemic lesion,

- localization of the lesion.

Patients with category 0 foot lesions (rest pain, no skin damage) were excluded from the study design.

\section{REVASCULARIZATION TECHNIQUE}

Revascularization techniques were divided into 3 groups: X-ray endovascular, surgical and hybrid. Endovascular revascularizations were performed 90 (73.2\%), surgical - $24(19.5 \%)$, hybrid - $9(7.3 \%)$.

To statistically accurately evaluate the results of revascularizations, it was decided to combine hybrid interventions with $\mathrm{X}$-ray interventions, given their relatively small number.

Catheter-directed thrombolysis was considered as a derivative of X-ray endovascular technique.

In the study group of patients as a separate method of treatment catheter-directed thrombolysis was not used, it was part of the staged treatment according to the scheme «thrombolysis-angioplasty».

\section{RESULTS}

Diabetic ischemic foot was diagnosed in 133 cases. Revascularization was considered inexpedient at the stage of the initial examination in 3 observations.

In 5 observations after angiography, revascularization by any method was considered impossible due to total occlusion of the main arteries of the leg and foot and underdeveloped collateral arteries.

123 revascularizations of 94 lower extremities were performed in 91 patients with ischemic diabetic foot. Attempts at revascularization were unsuccessful in 2 observations.

The analysis of long-term results within 1 year after revascularization was performed. 


\begin{tabular}{|l|c|c|}
\hline \multicolumn{1}{|c|}{ Total number: 123 revascularizations } & Number & percents \\
\hline Amputation-free survival & 101 & $85,40 \%$ \\
\hline Wound-healing & 77 & $62,60 \%$ \\
\hline Avoidance of repeated revascularization & 97 & $78,90 \%$ \\
\hline Functional capacity of the foot & 98 & $79,70 \%$ \\
\hline
\end{tabular}

Amputation-free survival was noted in $85.4 \%$ of cases, wound-healing in $62.6 \%$, preservation of foot support function in $79.7 \%$, avoidance of repeated interventions in $78.9 \%$.

$5(5.5 \%)$ patients died, 2 of them $(2.2: \%)$ within 30 days after revascularization.

$5(5.5 \%)$ patients died, 2 of them (2.2:\%) within 30 days after revascularization.

\section{EVALUATION OF RESULTS}

The results of revascularization were evaluated according to the following criteria: amputation-free survival, healing of trophic lesions, repeated revascularization; preservation of the supporting function of the foot.

\section{STATISTICAL ANALYSIS}

Statistical analysis was performed using the statistical open access package EZR v. 1.54 (graphical user interface for R statistical software version 4.0.3, R Foundation for Statistical Computing, Vienna, Austria) [21].

\section{Method of revascularization}

A statistically significant difference ( $\mathrm{p}$. value $=0.046$ ) in the effectiveness of different revascularization techniques was revealed.

\section{Amputation-free survival}

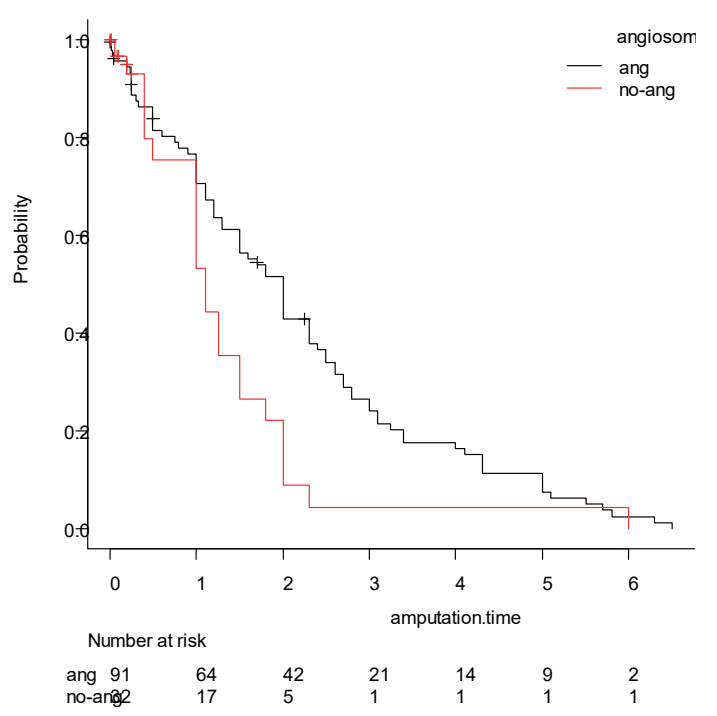

The probability of amputation-free survival for 1 year with endovascular or hybrid techniques $-87.9 \%$, with vascular surgery $-75.0 \%$.

\section{Angiosomal concept.}

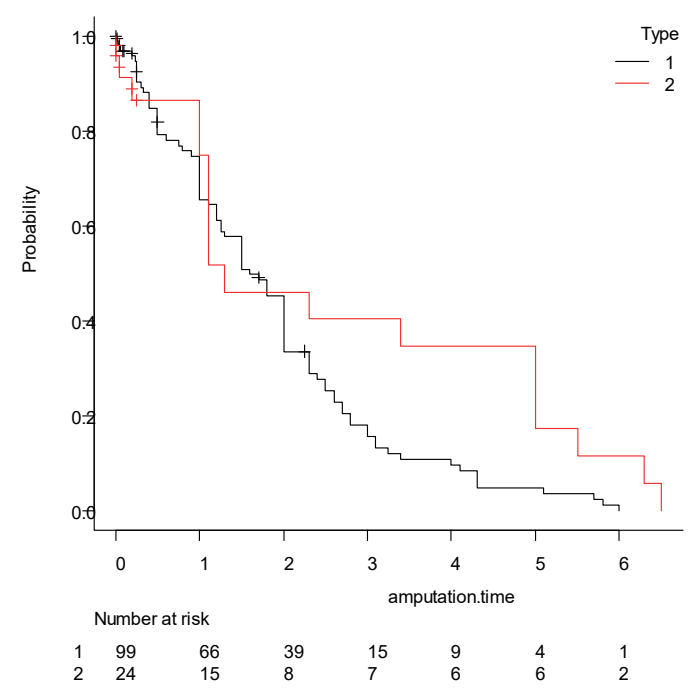

There was also a statistically significant difference in adherence to the angiosomal concept in revascularization of the foot and leg (p.value $=0.018)$.

The probability of amputation-free survival within 1 year in angiosomal revascularization (direct revascularization) $-91,9 \%$, in indirect (indirect revascularization) $-71.9 \%$.

\section{Wound healing}

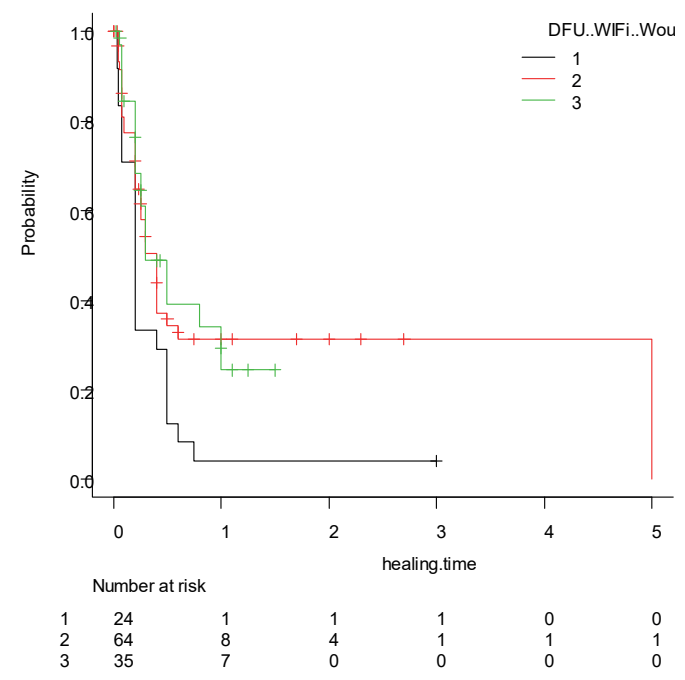

There was a statistically significant difference (p.value $=0.015$ ) of healing from the category of foot tissue lesions by WIFi. Healing during the year with lesions of 1 cat. noted in $95.8 \%$ of observations, 2 cat in $54.0 \%, 3$ cat. in $55.6 \%$. 
There was no statistically significant dependence on the method of intervention ( $p$.value $=0.086$ ). The median healing was 0.25 for X-ray endovascular and 0.6 for surgical revascularization. On the basis of the received statistical data it is possible to assume a tendency to the best healing at endovascular interventions.

\section{Repeated revascularization.}

There was no statistically significant dependence of the risk of re-intervention on the chosen method, adherence to the angiosomal concept, localization of arterial lesions and features of trophic changes.

There was no statistically significant difference between primary and repeated revascularizations in terms of amputation avoidance $(\mathrm{p}$. value $=0.301)$ and healing (p.value $=0.119$ ). It is possible to note a tendency to the best healing after primary revascularizations.

\section{CONCLUSIONS}

Differentiated choice of revascularization technique allows to increase the number of patients to be revascularized to $92,4 \%$, to reach of the level amputation-free survival to $85,4 \%$, to reach of the level wound-healing to $62,6 \%$, to salvage of foot support function to $79,7 \%$, perform interventions in patients with a high probability of limb amputation. allows:

Differentiated choice of revascularization technique

- the number of patients to be revascularized can be increased to $92,4 \%$.

- the level amputation-free survival can be reach to $85,4 \%$,

- the level wound-healing can be reach to $62,6 \%$,

- the foot support function can be salvage in $79,7 \%$,
- revascularization can be performed in patients with a high probability of high limb amputation.

The angiosomal concept when performing endovascular techniques of revascularization makes possible effective targeted restoration of blood flow in the area of trophic lesions.

Arterial lesions, in which one of the methods is predicted to be ineffective, are indications for a combination of techniques - hybrid revascularization.

Repeated revascularization can be an effective way to prolong the life of the limb in the postoperative period.

\section{KEYWORDS}

Diabetic foot, ischemia, diabetes mellitus, revascularization, peripheral artery disease, amputation,

\section{FINANCING}

The work was performed in accordance with the dissertation research of the applicant D. Shapovalov.

The authors did not receive financial support from companies producing drugs and medical devices.

\section{CONFLICT OF INTEREST}

The authors state that there is no conflict of interest.

\section{APPROVAL OF THE ETHICS COMMITTEE}

The clinical study was approved at a meeting of the commission on ethics of DNU «Scientific and Practical Center for Preventive and Clinical Medicine» DUS, from 29.01.2018.

\section{ЛITEPATУPA}

1. Hirsch, A.T., Hiatt, W. R. Partners: PAD, Awareness, Risk and Treatment: New Resources for Survival. Vascular Medicine. 2001. 6. (3 Suppl). P. 9-12. URL: https:// doi.org/10.1177/1358836x0100600i103

2. Roglic G. Global report on diabetes World Health Organization. 2016. URL: https://www.who.int/ publications/i/item/9789241565257

3. Delivery of care to diabetic patients with foot ulcers in daily practice: results of the Eurodiale Study, a prospective cohort study / Prompers L., et al. Diabetic Medicine. 2008. 25 (6). P. 700-707. URL: https://doi. org/10.1111/j.1464-5491.2008.02445.x

4. IWGDF Editorial Board Practical Guidelines on the prevention and management of diabetic foot disease (IWGDF 2019 update) / Nicolaas C. S., et al. Dia- betes. Metabolism Reearch and Reviews. 2020. 36 Suppl 1. e3266. URL: https://pubmed.ncbi.nlm.nih. gov/32176447/ https://doi.org/10.1002/dmrr.3266

5. Armstrong D., Boulton A. Bus S. Diabetic Foot U1cers and Their Recurrence. The New England journal of medicine. 2017. 376(24). P. 2367-2375. URL: https://pubmed.ncbi.nlm.nih.gov/28614678/ https:// doi.org/10.1056/nejmra1615439

6. The North-West Diabetes Foot Care Study: incidence of, and risk factors for, new diabetic foot ulceration in a community-based patient cohort / Abbott C., Carrington A., Ashe H., Bath S., Every L. C., Griffiths J., Boulton A.. Diabetic Medicine. 2002. 19 (5). P. 377-384. URL: https://pubmed.ncbi.nlm.nih.gov/12027925/ https://doi.org/10.1046/j.1464-5491.2002.00698.x 
7. Features of revascularization of the lower extremity in patients with diabetic foot / Shapovalov D., Hupalo Y., Shaprynskyi V., Shamray-Sas A., Kutsin A., Gurianov V.. Clinical and preventive medicine. 2020. № 3(12). URL: https://doi. org/10.1046/j.1464-5491.2002.00698.x

8. International Working Group on the Diabetic Foot (IWGDF) Guidelines on the Prevention and Management of Diabetic Foot Disease / Monteiro-Soares M., Russell D., Boyko E., Jeffcoate W., Mills J., Morbach S., Game F. Diabetes/Metbolism research and reviews. 2019. 36 (1). P. 3273. https://pubmed.ncbi.nlm.nih. gov/32176445/ https://doi.org/10.1002/dmrr.3273

9. Moulik P., Mtonga R., Gill G. Amputation and Mortality in New-Onset Diabetic Foot Ulcers Stratified by Etiology. Diabetes Care. 2003. 26(2). P. 491-494 URL: https://doi.org/10.2337/diacare.26.2.491

10.Trends in Lower-Extremity Amputations in People With and Without Diabetes in Spain, 2001-2008 / Lópezde-Andrés A., et al. Epidemiology Health Services Research. 2011. 34(7). P. 1570-1576. URL: https:// doi.org/10.2337/dc11-0077

11.Rümenapf G., Morbach S. Amputation StatisticsHow to Interpret Them? Deutsches Arzteblatt International. 2017. 114(8). P. 128-129. URL: https://doi. org/10.3238/arzteb1.2017.0128

12. Centers for Disease Control and Prevention. DiabetesRelated Amputations of Lower Extremities in the Medicare Population - Minnesota, 1993-1995. Morbidity and Mortality weekly report. 2008.47 (31). P. 649-652. https://pubmed.ncbi.nlm.nih.gov/9716396/

13.Spoden M., Nimptsch U., Mansky T. Amputation rates of the lower limb by amputation level - observational study using German national hospital discharge data from 2005 to 2015. BMC Health Services Research. 2019. 19 (1). 8. URL: https://doi.org/10.1186/ s12913-018-3759-5

14. BASIL Trial Participants: Bypass versus Angioplasty in Severe Ischaemia of the Leg (BASIL) trial: A survival prediction model to facilitate clinical decision making / Bradbury A. W., et al. Journal of Vasularc Surgery,
2010. 51. P. 52-68. URL: https://doi.org/10.1161/01. cir.0000137913.26087.f0

15.Successful Revascularization has a Significant Impact on Limb Salvage Rate and Wound Healing for Patients with Diabetic Foot Ulcers: Single-Centre Retrospective Analysis with a Multidisciplinary Approach / Caetano A., et al.. Cardiovascular and Interventional Radiology. 2020. 43(10). P. 1449-1459. URL: https://doi. org/10.1007/s00270-020-02604-4

16.A Definition of Advanced Types of Atherosclerotic Lesions and a Histological Classification of Atherosclerosis. A Report From the Committee on Vascular Lesions of the Council on Arteriosclerosis, American Heart Association. Originally published / Stary H., et al. Circulation. 1995. 92. P. 1355-1374. URL: https:// doi.org/10.1161/01.cir.92.5.1355

17. Taylor G. I. The angiosomes of the body and their supply to perforator flaps / Department of Plastic Surgery, Royal Melbourne Hospital. 7th Floor. Clinics in Plastic Surgery, 2003. 30. P. 331-342URL: https://doi. org/10.1016/s0094-1298(03)00034-8

18. Angiosomes of the Foot and Ankle and Clinical Implications for Limb Salvage: Reconstruction, Incisions, and Revascularization / Attinger C., et al. Plastic and Reconstruction Surgery. 2006. 117. P. 261-293. URL: doi:10.1097/01.prs.0000222582.84385.54.

19.TASC II Working Group. Inter-Society Consensus for the Management of Peripheral Arterial Disease (TASC II) / Norgren L., et al. Journal of Vascular Surgery. 2007. 45 (1). P. 5-67. URL: https://doi.org/10.1016/j.jvs.2006.12.037

20.GVG Writing Group for the Joint Guidelines of the Society for Vascular Surgery (SVS), European Society for Vascular Surgery (ESVS) and World Federation of Vascular Societies (WFVS) / Conte M. S., et al. Global Vascular Guidelines on the Management of Chronic Limb-Threating Ichemia, 2019. 58. P. 1-109. URL: https://doi.org/10.1016/j.jvs.2019.02.016

21. Kanda Y. Investigation of the freely available easy-touse software 'EZR' for medical statistics. Bone Marrow Transplant. 2013. 48. P. 452-458. URL: https:// doi.org/10.1038/bmt.2012.244

\section{REFERENCES}

1. Hirsch, A.T., Hiatt, W.R. (2001). Partners: PAD, Awareness, Risk and Treatment: New Resources for Survival. Vascular Medicine, 6, 3, 9-12. Retrieved from: https:// doi.org/10.1177/1358836x0100600i103

2. Roglic, G. (2016). Global report on diabetes World Health Organization.. Retrieved from: https://www. who.int/publications/i/item/9789241565257

3. Prompers, L., et al. (2008). Delivery of care to diabetic patients with foot ulcers in daily practice: results of the Eurodiale Study, a prospective cohort study. Diabetic
Medicine, 25 (6), 700-707. Retrieved from: https:// doi.org/10.1111/j.1464-5491.2008.02445.x

4. Nicolaas C. S., et al. (2020). IWGDF Editorial Board Practical Guidelines on the prevention and management of diabetic foot disease (IWGDF 2019 update). Diabetes. Metabolism Reearch and Reviews, 36, 1, e3266. Retrieved from: https://doi.org/10.1002/dmrr.3266

5. Armstrong D., Boulton A., Bus S. (2017). Diabetic Foot Ulcers and Their Recurrence. The New England journal of medicine, 376(24), 2367-2375. Retrieved from: 
https://pubmed.ncbi.nlm.nih.gov/28614678/ https:// doi.org/10.1056/nejmra1615439

6. The North-West Diabetes Foot Care Study: incidence of, and risk factors for, new diabetic foot ulceration in a community-based patient cohort (2002) / Abbott C., et al. Diabetic Medicine, 19 (5), 377-384. Retrieved from: https://doi. org/10.1046/j.1464-5491.2002.00698.x

7. Features of revascularization of the lower extremity in patients with diabetic foot / Shapovalov D., Hupalo Y., Shaprynskyi V., Shamray-Sas A., Kutsin A., Gurianov V. Clinical and preventive medicine, 2020, № 3(12), Retrieved from: https://doi. org/10.1046/j.1464-5491.2002.00698.x

8. International Working Group on the Diabetic Foot (IWGDF) Guidelines on the Prevention and Management of Diabetic Foot Disease (2019) / MonteiroSoares M., Russell D., Boyko E., Jeffcoate W., Mills J., Morbach S., Game F. Diabetes/Metbolism research and reviews. 36 (1). P. 3273. Retrieved from: https:// pubmed.ncbi.nlm.nih.gov/32176445

9. Moulik P., Mtonga R., Gill G. (2003). Amputation and Mortality in New-Onset Diabetic Foot Ulcers Stratified by Etiology. Diabetes Care, 26(2), 491-494. Retrieved from: https://doi.org/10.2337/diacare.26.2.491

10.Trends in Lower-Extremity Amputations in People With and Without Diabetes in Spain, 2001-2008 (2011) / López-de-Andrés A., et al. Epidemiology Health Services Research, 34(7), 1570-1576. Retrieved from: https://doi.org/10.2337/dc11-0077

11. Rümenapf G., Morbach S. (2017). Amputation Statistics-How to Interpret Them? Deutsches Arzteblatt International, 114(8), 128-129. Retrieved from: https:// doi.org/10.3238/arztebl.2017.0128

12. Centers for Disease Control and Prevention. Diabetes-Related Amputations of Lower Extremities in the Medicare Population - Minnesota, 1993-1995 (2008). Morbidity and Mortality weekly report, 47 (31), 649-652. Retrieved from: https://pubmed.ncbi. nlm.nih.gov/9716396/

13.Spoden M., Nimptsch U., Mansky T. (2019). Amputation rates of the lower limb by amputation level observational study using German national hospital discharge data from 2005 to 2015. BMC Health Services Research, 19 (1), 8. Retrieved from: https://doi. org/10.1186/s12913-018-3759-5
14.BASIL Trial Participants: Bypass versus Angioplasty in Severe Ischaemia of the Leg (BASIL) trial: A survival prediction model to facilitate clinical decision making (2010) / Bradbury A. W., et al. Journal of Vasularc Surgery, 51, 52-68. Retrieved from: https://doi. org/10.1161/01.cir.0000137913.26087.f0

15.Successful Revascularization has a Significant Impact on Limb Salvage Rate and Wound Healing for Patients with Diabetic Foot Ulcers: Single-Centre Retrospective Analysis with a Multidisciplinary Approach (2020) / Caetano A., et al. Cardiovascular and Interventional Radiology, 43(10), 1449-1459. Retrieved from: https:// doi.org/10.1007/s00270-020-02604-4

16.A Definition of Advanced Types of Atherosclerotic Lesions and a Histological Classification of Atherosclerosis (1995). A Report From the Committee on Vascular Lesions of the Council on Arteriosclerosis, American Heart Association. Originally published / Stary H., et al. Circulation, 92, 1355-1374. Retrieved from: https:// doi.org/10.1161/01.cir.92.5.1355

17. Taylor G. I. (2003). The angiosomes of the body and their supply to perforator flaps / Department of Plastic Surgery, Royal Melbourne Hospital. 7th Floor. Clinics in Plastic Surgery, 30, 331-342. Retrieved from: https:// doi.org/10.1016/s0094-1298(03)00034-8

18. Angiosomes of the Foot and Ankle and Clinical Implications for Limb Salvage: Reconstruction, Incisions, and Revascularization (2006) / Attinger C., et al. Plastic and Reconstruction Surgery, 117, 261-293. Retrieved from: doi:10.1097/01.prs.0000222582.84385.54

19.TASC II Working Group. Inter-Society Consensus for the Management of Peripheral Arterial Disease (TASC II) (2007) / Norgren L., et al. Journal of Vascular Surgery, 45 (1), 5-67. Retrieved from: https://doi. org/10.1016/j.jvs.2006.12.037

20.GVG Writing Group for the Joint Guidelines of the Society for Vascular Surgery (SVS), European Society for Vascular Surgery (ESVS) and World Federation of Vascular Societies (WFVS) (2019) / Conte M. S., et al. Global Vascular Guidelines on the Management of Chronic Limb-Threating Ichemia, 58, 1-109. Retrieved from: https://doi.org/10.1016/j.jvs.2019.02.016

21. Kanda Y. (2013). Investigation of the freely available easy-to-use software 'EZR' for medical statistics. Bone Marrow Transplant, 48, 452-458. Retrieved from: https://doi.org/10.1038/bmt.2012.244 


\section{Резюме}

\section{ВИБІР МЕТОДИКИ РЕВАСКУЛЯРИЗАЦІЇ У ХВОРИХ НА ІШЕМІЧНУ ДІАБЕТИЧНУ СТОПУ д. Ю. Шаповалов}

Державна наукова установа «Науково-практичний центр профілактичної та клінічної медицини» Державного управління справами, м.Київ, Україна

Вступ. Ішемічна діабетична стопа визначається трофічними розладами стопи внаслідок поєднання атеросклерозу артерій та діабетичних уражень. Особливості ішемічної діабетичної стопи вимагають окремого підходу до реваскуляризації. Сьогодні у світі немає загальноприйнятих рекомендацій щодо реваскуляризації діабетичної стопи. Вибір техніки реваскуляризації залишається відкритим питанням.

Мета дослідження. Проаналізувати ефективність диференційованого застосування методів втручання реваскуляризації для лікування ішемічної діабетичної стопи.

Етапи диференційованого вибору реваскуляризації. Ми визначили сім кроків: визначення показань до реваскуляризації, визначення критичного артеріального сегмента. оцінка гемодинамічної компенсації, визначення доцільності реваскуляризації, вибір техніки реваскуляризації, виконання реваскуляризації, активний післяопераційний моніторинг.

Матеріали та методи. Аіабетична ішемічна стопа була діагностована в 133 спостереженнях. Було проведено 123 реваскуляризації 94 нижніх кінцівок у 91 пацієнта з ішемічною діабетичною стопою. Пацієнтам виконували ендоваскулярну, хірургічну або гібридну реваскуляризацію.

Результати. Реваскуляризацію виконали у 92,4\% пацієнтів з ішемічною діабетичною стопою. Виживання без ампутації вілзначалося у 85,4\% випадків, загоєння ран -у 62,6\%, збереження опорної функції стопи - у 79,7\%, уникнення повторних втручань-у 78,9\%. Померло 5,5\% пацієнтів, 2,2\% 3 них впродовж 30 днів після реваскуляризації.

Висновки. Аиференційований вибір техніки реваскуляризації дозволяє досягти кількості пацієнтів, які підлягають реваскуляризації, до 92,4\%, досягти рівня виживання без ампутації 85,4\%, досягти рівня загоєння ран 62,6\%, зберегти функцію підтримки стопи в 79,7\%, а також виконувати втручання пацієнтам з високою ймовірністю ампутації високої кінцівки.

Ключові слова: захворювання периферичних артерій, діабетична стопа, реваскуляризація, ангіопластика, хірургія судин, ендоваскулярне лікування. 


\section{Резюме}

\section{Д. Ю. ШАПОВАЛОВ \\ Выбор методики реваскуляризации у пациентов с ишемической диабетической стопой}

Государственное научное учреждение «Научно-практический центр профилактической и клинической медицины» Государственного управления делами, г. Киев, Украина

Вступление. Ишемическая диабетическая стопа определяется трофическими расстройствами стопы вследствие сочетания атеросклероза артерий и диабетических поражений. Особенности ишемической диабетической стопы требуют отдельного подхода к реваскуляризации. Сегодня в мире нет общепринятых рекомендаций по реваскуляризации диабетической стопы. Выбор техники реваскуляризации остается открытым вопросом.

Цель исследования. Проанализировать эффективность дифференцированного применения методов вмешательства реваскуляризации для лечения ишемической диабетической стопы.

Этапы дифференцированного выбора реваскуляризации. Мы определили семь шагов: определение показаний к реваскуляризации, определения критического артериального сегмента. оценка гемодинамической компенсации, определение целесообразности реваскуляризации, выбор техники реваскуляризации, выполнение реваскуляризации, активный послеоперационный мониторинг.

Материалы и методы. Аиабетическая ишемическая стопа была диагностирована в 133 наблюдениях. Было проведено 123 реваскуляризации 94 нижних конечностей у 91 пациента с ишемической диабетической стопой. Пациентам выполняли эндоваскулярную, хирургическую или гибридную реваскуляризации.

Результаты. Реваскуляризацию выполнили у 92,4\% пациентов с ишемической диабетической стопой. Выживаемость без ампутации отмечалась в 85,4\% случаев, заживление ран - в 62,6\%, сохранение опорной функции стопы - в 79,7\%, избежание повторных вмешательств - в 78,9\%. Умерло 5,5\% пациентов, 2,2\% из них в течение 30 дней после реваскуляризации.

Выводы. Аифференцированный выбор техники реваскуляризации позволяет достичь количества пациентов, которые подлежат реваскуляризации, в 92,4\%, достичь уровня выживаемости без ампутации $85,4 \%$, достичь уровня заживления ран 62,6\%, сохранить функцию поддержки стопы в 79,7\%, а также выполнять вмешательства пациентам с высокой вероятностью ампутации высокой конечности.

Ключевые слова: заболевания периферических артерий, диабетическая стопа, реваскуляризация, ангиопластика, сосудистая хирургия, эндоваскулярное лечение.

Інформація про авторів знаходиться на сайті http://www.cp-medical.com.

Дата надходження до редакиї - 29.10.2021 p. 